\title{
The southernmost occurrence of the Striated Scops Owl (Otus brucei) in Africa and a critical evaluation of Egyptian records of the species
}

\author{
István Moldován ${ }^{1,2}$ \\ 1- Present address: Villa 9030, Hurghada, Red Sea District, Egypt. \\ 2- Permanent address: Tg. Mures, str. C. R. Vivu 11/D, ap 8., Romania
}

\begin{abstract}
The first fully documented record of Striated Scops Owl from the African continental part is presented. The status of the species in Egypt and the region is presented, with discussions on the possible misidentification of the species level.
\end{abstract}

Keywords: Scops Owl, Otus scops, distribution, Aswan, Egypt

\section{Introduction}

The species was described by Octavian Allan Hume in 1873 as the Striated Scops Owl (Ephialtes brucei), but it has multiple English names: the Pale Scops Owl, Bruce's Scops Owl or the Desert Screech Owl. Originally it was included as a subspecies of the European Scops Owl (Otus scops), but DNA evidence and vocalizations have proved its specific status. It has a large range, with an estimated global extent of occurrence of $1,000,000-10,000,000 \mathrm{~km}^{2}$. It has a large global population, including some 20-100 individuals in Turkey (Birdlife International, in prep.). Global population trends have not been quantified, but the species is not believed to approach the thresholds for IUCN Red Listing. The species has been evaluated as Least Concern (BirdLife International 2004), but in Europe (Turkey) it seems to have undergone a substantial decline between 1990 to 2000, and is considered Critically Endangered since the breeding population is estimated at only 10 to 50 pairs. A polytypic species, four to five distinct races are recognized, and some authors refer to a sixth extralimital race from Socotra Island. The most recognized races are (Cramp 1994):

- obsoletus (Cabanis, 1875) from Syria, N Iraq, Turkmenistan, northern Afghanistan, and the lowlands of Uzbekistan east to Samarkand; wing length ô 0 ? 150-168 mm;

- exiguus (Mukherjee, 1958) from Israel, central Iraq, southern Iran, southern Afghanistan, and western Pakistan north to Bannu and perhaps Kohat; wing length $\widehat{\jmath}$ 우 139-163 mm;

- brucei (Hume, 1873) from the eastern Aral Sea, Syr-Dar'ya valley, Fergana basin, and the mountain valleys of northern Tadjikistan and Kirgiziya;

-semenowi (Zarudny \& Härms, 1902) from the Tarim basin (China) east to c. $88^{\circ} \mathrm{E}$ and the mountain valleys of southern Tadjikistan, eastern Afghanistan, and Pakistan north of $35^{\circ} \mathrm{N}$;

- pamelae (Bates, 1937) from Arabia (except the north-east) and west of the Zagros mountains in Iran (and perhaps this race in the intervening southern Iraq and in southern Israel or Sinai). Populations from S and SW Arabia are considered conspecific with the African Scops Owl Otus senegalensis (Harris et al. 1996); this was originally described as a form of Otus senegalensis (Bates, 1937)

- socotranus (Grant \& Forbes, 1899) from Socotra Island. This is the smallest subspecies (wing length 125-135 mm), and some authors consider it a subspecies of the African Scops Owl Otus senegalensis. In the last few years (2005-2008) several visiting birders have recorded the call of socotranus, and it is distinctively different from African, European and Striated Scops Owl. It is perhaps most similar to the Oriental Scops Owl Otus sunia, but has a twonote call. Thus it is best treated as a separate endemic species (Oláh pers.comm.), but further research is needed.

The two species of Scops owls occurring in the region are hard to distinguish in the field. I have compiled the most diagnostic morphological features of Striated and Common Scops

\footnotetext{
* Author for correspondence. email : idegenvezeto@yahoo.com
} 
Owls in Table 1 in order to make identification easier both in the field and in hand.

Table 1: Diagnostic features of the two Scops Owls in Egypt

\begin{tabular}{|c|c|c|}
\hline & $\begin{array}{l}\text { Common Scops Owl } \\
\text { Otus scops }\end{array}$ & $\begin{array}{l}\text { Striated Scops Owl } \\
\text { Otus brucei }\end{array}$ \\
\hline Head & $\begin{array}{l}\text { - brown to grey (intermediate forms occur } \\
\text { widely) } \\
\text { - white spots on crown and hind neck } \\
\text { - dark region around eyes. } \\
\text { - bill grey } \\
\text { - somewhat rounded head }\end{array}$ & $\begin{array}{l}\text { - facial disc pale grey, with almost no } \\
\text { contrast } \\
\text { - lack of any rufous tones } \\
\text { - lack of white spots on crown and mantle, } \\
\text { more uniform-colored } \\
\text { - pale horn-yellow base to bill } \\
\text { - flat-topped head }\end{array}$ \\
\hline Body & $\begin{array}{l}\text { - a multitude of forms occur between brown } \\
\text { and grey. } \\
\text { - blackish shaft-streaks with cross-bars, } \\
\text { some much broader than the others, and } \\
\text { heavier horizontal vermiculations. }\end{array}$ & $\begin{array}{l}\text { - generally ground color paler grey or } \\
\text { sandier } \\
\text { - better-defined longitudinal feather-centre } \\
\text { streaks } \\
\text { - variable indistinct broken dark horizontal } \\
\text { cross-bars, often indistinct or absent; more } \\
\text { finely streaked }\end{array}$ \\
\hline Wing & $\begin{array}{l}\text { - large whitish spots on the outer scapulars } \\
\text { - } 10 \text { th (outer) primary }=5 / 7^{\text {th }}, 9^{\text {th }} \text { primary } \\
\text { subequal with the } 3^{\text {rd }} \\
\text { - wing length } 143-167 \mathrm{~mm}\end{array}$ & $\begin{array}{l}\text { - large pale spots on the outer scapulars are } \\
\text { sandy to warm buff, or often pale cream or } \\
\text { sandy } \\
\text { - longest } \mathrm{p} 8 \text { (socotranus and pamelae } \mathrm{p} 7) \\
\text { - 10th (outer) primary }=4 / 5^{\text {th }}=5 \text { th) } \\
\text { primary shorter than the } 3^{\text {rd }} \\
\text { - wing length } 139-169 \mathrm{~mm}\end{array}$ \\
\hline Tail & $\begin{array}{l}\text { - } 5 \text { to } 8 \text { light bars beyond upper tail coverts } \\
\text { - tail length: } 60-76 \mathrm{~mm}\end{array}$ & $\begin{array}{l}\text { - } 4 \text { to } 6 \text { light bars beyond upper tail coverts, } \\
\text { much wider and less spectacled at the } \\
\text { borders. } \\
\text { - at the central rectrices only 2-4 bars visible } \\
\text { beyond tail coverts } \\
\text { - tail length: } 66-78 \mathrm{~mm}\end{array}$ \\
\hline Foot & $\begin{array}{l}\text { - foot feathering always restricted to the } \\
\text { tarsus; living toes bare. } \\
\text { - tarsus length: } 23-29 \\
\text { - claw grey-brown with darker tips }\end{array}$ & $\begin{array}{l}\text { - foot feathering extends onto bases of toes, } \\
\text { often to the second phalanx on the third } \\
\text { toe. } \\
\text { - tarsus: } 26-35 \mathrm{~mm}\end{array}$ \\
\hline Vocalization & $\begin{array}{l}\text { - male call a single monosyllabic flute-like } \\
\text { note with downward inflections (kyoot), } \\
\text { lasting } 0.2-0.3 \text { seconds, repeated at } \\
\text { intervals of about } 2-3 \text { seconds in long } \\
\text { sequences. }\end{array}$ & $\begin{array}{l}\text { - male call consisting of well-separated } \\
\text { dove-like notes uttered in long sequences } \\
\text { (whookh-whook, recalling that of the Stock } \\
\text { Dove Columba oenas) at intervals varying } \\
\text { between } 0.6 \text { and } 1 \text { second. }\end{array}$ \\
\hline
\end{tabular}

The breeding range of Striated Scops Owl in the Western Palearctic is still poorly understood; the only certain breeding areas are in Iraq and Turkey, and it has been proven to breed in Israel (Shirihai 1996) where it is a regular wintering visitor. It may breed in Syria and Lebanon, but this has not yet been documented.

The Striated Scops Owl has similar requirements as the Eurasian Scops Owl, being largely insectivorous but also preying on small mammals and passerines, but it prefers more arid habitats with scattered acacia trees. It seems to be a partial migrant from its Asian breeding areas to the west, to a wintering range in southern Israel, Sinai and (according to the present record) extending further south to the continental part of Africa. 


\section{History of records in Egypt}

A total of nine records of the Striated Scops Owl are claimed within the political borders of Egypt, seven of them from Sinai. Records previous to my own $(n=8)$ are detailed below.

Two records derive from the 19th century: one specimen was collected at El Tor in November 1823 by Ehrenberg, and the other by Zarudny near "Um Heshim" on 1 December 1891 (Meinertzhagen 1930). Although the records collated by Colonel Richard Meinertzhagen should be treated with care, if the specimens are still preserved somewhere, they can be verified.

One record from Wadi Taba $\left(29^{\circ} 28^{\prime} 48^{\prime \prime} \mathrm{N}\right.$; 34 51' 16" E) on 24 November 1991 by Andrew Grieve (pers. comm.), photographed while resting in a tall acacia tree, the first documented, published and accepted record of a Striated Scops Owl within the political borders of Egypt. This is probably the specimen mentioned by Shirihai et al. (1996) as overwintering at (Wadi) Taba in November-February 1991/92.

On 18 August 2005 while mist-netting for bats at Sheikh Awad in the St Katherine Protectorate, Dr. Christian Dietz caught one specimen that was identified as a Striated Scops Owl by one of the local rangers (Dietz, pers. comm.); however, the photographs (kindly provided by Dr. Dietz) show a typical grey form of the European Scops Owl. Because of this catch, Meakin et al. (2005) regarded the Striated Scops Owl as a resident species in the St. Katherine Protectorate.

On 9 of October 2007, a presumably immature Scops Owl (Otus sp.) was captured with a mist net at Hurghada city sewage works. The bird was photographed, ringed and identified as Striated Scops Owl by Prof. Przemyslaw Busse (pers. comm.). There was much debate regarding the identity of this specimen on the Internet and mentioned even in the local media (Hoath 2008). My initial impression was that it was a darker owl than one would expect of a desert/semi-desert species (i.e. O.b.obsoletus). My second impression was of a juvenile: the ear-tufts are very tiny; the feathers of the crown and back do not appear to be those of a mature bird; the crown, facial and general markings do not appear as well defined as seen in a mature bird; the facial disc is faint and incomplete; the pink around the eyes suggests that the eyes are not fully feathered, as in adult plumage. The main morphometric measurements are the following: wing $166 \mathrm{~mm}$, tail $78 \mathrm{~mm}$, weight $81.5 \mathrm{~g}$. So if this was a juvenile, the streaking on the breast would make it a Scops Owl since the breast of the juvenile Striated Scops Owl is barred (Svensson \& Grant 1999: 215). In the end, the informal consensus of those who examined this record rejected it as a Striated Scops Owl, regarding it as a European Scops Owl. The body stripes and the large cream-colored spots on the scapulars indicate a Striated Scops Owl, but the reddish tones on the chin, hind neck and upper part of the breast, the obvious cross-shaped markings on the neck and the darker region around the eyes strongly indicate a European Scops Owl. The identification clue considered decisive for the final verdict is the foot feathering, which is limited to the tarsus on this specimen, while in the Striated Scops Owl it extends to the base of the toes, often on the third toe reaching along the second phalanx. Photos of this specimen are available on the Egyptian Birding Group web page (http://pets.groups.yahoo.com/group/EgyBirdGroup/, under photo rarities, Otus scops, Hurghada 2007).

Mindy Baha El Din has kindly submitted, among other records and comments, three records which could not be verified: one from South Sinai by Tom and Maria Moore, but the observers cannot be traced; one record from the St. Katherine rangers (Hussein); and one sighting by an unknown observer on an unknown date from Hurghada (Um Magawish).

\section{Circumstances of the present observation}

On 6 December 2007, while leading a group of tourists on Agilika Island, nowadays erroneously known and mentioned as Philae Island (Aswan Reservoir, Egypt, 23 58'-24'02' N, $32^{\circ} 51^{\prime}-32^{\circ} 57^{\prime}$ E), my attention was drawn to the call of two Common Bulbuls (Pycnonotus 
barbatus), and a flock of House Sparrows (Passer domesticus) mobbing in an acacia tree (Acacia nilotica). Upon getting closer, I observed a Scops Owl flying away from the tree, a few meters above the mob. Unfortunately, I was only able to take one useful photo before the owl flew away, disappearing in the dense vegetation. The specimen was observed for about four minutes, from a distance of $15 \mathrm{~m}$ with an Olympus binocular (10x50). The habitat is a mixture of ornamental trees and bushes (bougainvillea, oleander) with native vegetation (Acacia nilotica, Phragmites australis, Hyphaene thebaica, Ceratophyllum demersum, Potamogeton crispus).

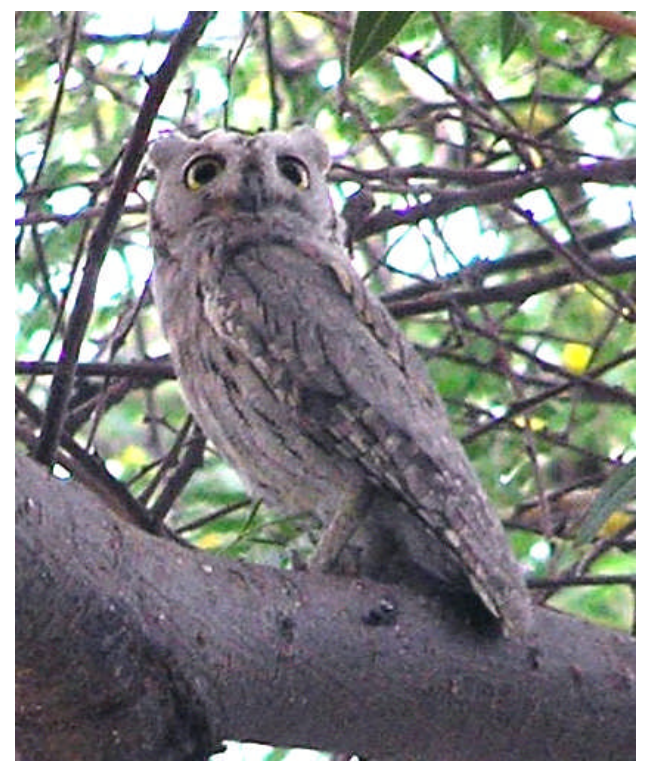

\section{Description of the bird}

Overall coloration is uniform pale-grey, as is to be expected from a desert/semi desert dwelling bird, with finer striations than the Eurasian Scops Owl, and lacking any brownish shape on the plumage. Its underparts have fine, dark stripes but lack the fine bars typical of the Eurasian Scops Owl ('Maltese cross'-shaped markings). The facial disc is distinctly pale, with almost no contrast between the area around eyes and rest of the facial disc. It has obvious buff-creamy spots on the outer scapulars, which are white in the Eurasian Scops Owl. Unfortunately one of the best identification clues, the feathering of the toes, was not observed, and cannot be seen in the photograph because the toes are hidden behind a branch of the acacia tree.

The author has no previous experience of this species, but has extensive experience of the Eurasian Scops Owl, both in the hand and from field observation in the European breeding areas.

\section{Discussion}

A single record is highly likely to be an accidental occurrence of the species in Africa, but the low number of observers visiting Egypt (especially in the winter), and the elusive behavior of the species, can explain the very rare reports of the Striated Scops Owls from Egypt, assuming that it is an uncommon winter visitor. Most Scops owls of both species are discovered by chance when flushed from their roosting sites during the day. It is very likely to be confused even in the hand (as in two of the nine records above) with the sometimes extremely similar grey phase of the Common Scops Owl.

The Striated Scops Owl is a regular wintering bird in south Israel (D Forsman, pers. comm.; Shirihai, 1996), and has even been recorded breeding there (Shirihai, 1996); thus it may be a winter visitor even in the continental part of Egypt, but much overlooked in the past. 
Despite the fact that the Striated Scops Owl is considered to be a partial migrant, some populations may be longer-distance migrants, wintering in still unknown territories. Fry et al. (1988: 114-5) state that its range and status are "Palearctic migrant, rare in extreme NW Egypt", and their distribution map shows a rare non-breeding winter visitor to the Delta and down the Nile Valley to Cairo. I have been unable to trace on what basis this map was compiled, and the statement that it is "rare in extreme NW Egypt" should be considered a typing error, to be emended to "NE Egypt".

\section{Acknowledgements}

I thank to Mindy Baha El Din, John Bartley, Prof. Przemyslaw Busse, Jozsef Büki, Dr. Christian Dietz, Dick Forsman, Andrew Grieve, Sayed Abd El Halim, Mary Megalli, Killian Mullarney, Németh Lajos, Oláh János, Sándor D. Attila, Mathew White and Zalai Tamás. This article is a tribute to my friend and mentor, Tom Coles $†$ (1949-2008), who encouraged and guided me through the world of birding, and who supervised an earlier version of the present article, among countless other papers.

\section{References}

Bates GL (1937) Descriptions of two races of Arabian birds: Otus senegalensis pamelae and Chrysococcyx klaas arabicus. Bulletin of the British Ornithological Club 57: 150-151

Beaman M \& Madge S (1998) The Handbook of Bird Identification for Europe and Western Palearctic. Princeton University Press, Princeton, New Jersey, USA.

BirdLife International (2004) Birds in Europe: population estimates, trends and conservation status. Birdlife Conservation Series 12. BirdLife International, Cambridge, UK.

Cramp S (ed) (1994) Birds of the Western Palaearctic. Oxford University Press, Oxford, UK.

Fry CH, Keith S \& Urban EK (1988) The Birds of Africa. III. Academic Press, London.

Goodman SM \&Meininger PL (1986) Birds of Egypt. Oxford University Press, Oxford, UK.

Harris A, Shirihai H \& Christie D (1996) The Macmillan Birder's Guide to European and Middle Eastern Birds. 2nd edition, Trans-Atlantic Publications, London.

Hoath R (2008) Identity Crisis. Egypt Today 29(1)

Hume AO (1872) Novelties. Stray Feathers 1(1): 1-19.

König C, Weick F, Becking J-H (1999) Owls. A Guide to the Owls of the World. Pica Press \& Yale University Press, Yale, Connecticut, USA

Meakin K, de Kort SR, Gilbert H, Gilbert F, Zalat S, Mohi L, Ibrahim S, Griffin J \& the Volunteers of Operation Wallacea in Egypt (2005) Monitoring birds in St Katherine Protectorate Egypt. Egyptian Journal of Biology 7: 65-95.

Meinertzhagen R (1930) Nicoll's Birds of Egypt. Hugh Rees, London.

Mullarney K, Svensson L, Zetterström D \& Grant PJ (2005) The most complete field guide to the birds of Britain and Europe. Hungarian edition, Park Kiadó, Budapest, Hungary.

Ogilvie-Grant W.R \& Forbes O. Henry (1899) Description of the New Species Of Birds. Bulletin of the Liverpool Museum 2: 2.

Shirihai H (1996) The Birds of Israel. Academic Press, London.

Springuel I (2006) The desert garden: a practical guide. American University in Cairo Press, Cairo, Egypt.

Svensson L \& Grant PJ (1999) Bird Guide. Collins, London.

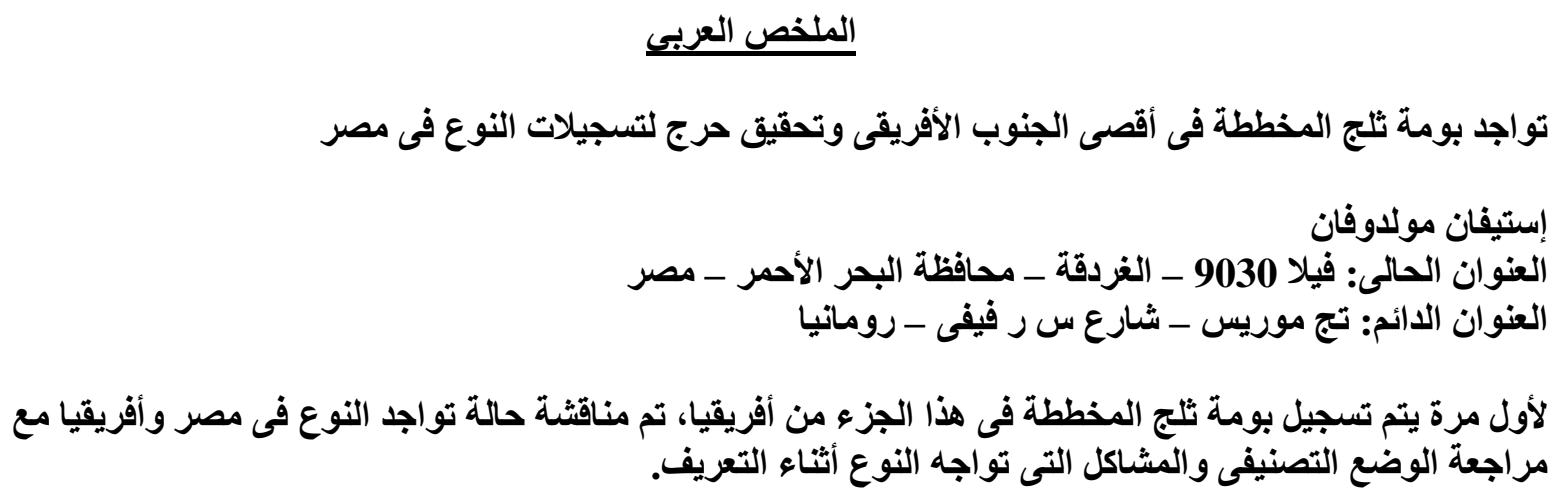

